\title{
Radionuclide angiocardiographic evaluation of the cardiovascular effects of recombinant human IGF-I in normal adults
}

Gianni Bisi, Valerio Podio, Maria Rosa Valetto, Fabio Broglio, Giovanni Bertuccio, Graziano Del Rio ${ }^{1}$, Muni F Boghen, Ferruccio Berti ${ }^{2}$, Eugenio E Muller ${ }^{2}$ and Ezio Ghigo

Division of Nuclear Medicine and Division of Endocrinology and Metabolism, Department of Internal Medicine, University of Turin, Turin, Italy, ${ }^{1}$ Division of Endocrinology and Metabolism, University of Modena, Modena, Italy and ${ }^{2}$ Department of Pharmacology, University of Milan, Milan, Italy

(Correspondence should be addressed to G Bisi, Divisione di Medicina Nucleare, Università di Torino, Ospedale Molinette, C.so Dogliotti 14, 10126 Torino, Italy)

\begin{abstract}
Objective: IGF-I possesses specific myocardial receptors and is able to promote cardiac remodelling and even inotropic effects in both humans and other animals. In fact, reduced cardiac mass and performance are present in GH deficiency and these alterations are counteracted by recombinant human (rh) GH replacement, restoring IGF-I levels. Recently, the acute administration of $60 \mu \mathrm{g} / \mathrm{kg}$ rhIGF-I has also been reported to be able to improve cardiac performance evaluated by echocardiography or impedance cardiography in normal subjects. The aim of our study was to verify the effects of a subcutaneous low dose of rhIGF-I $(20 \mu \mathrm{g} / \mathrm{kg})$ on cardiac performance in humans.

Methods: In six healthy male adults (mean \pm S.E.M.: $35.7 \pm 4.3$ years of age), the effects of rhIGF-I on left ventricular function evaluated by radionuclide angiocardiography and on circulating IGF-I, GH, insulin, glucose and catecholamines levels were studied.

Results: Administration of rhIGF-I increased circulating IGF-I (peak at +150 min vs baseline: $330.2 \pm$ 9.6 vs $199.7 \pm 8.7 \mu \mathrm{g} / \mathrm{l}, \mathrm{P}<0.03$ ) to levels which persisted similarly up to $+180 \mathrm{~min}$. Neither $\mathrm{GH}$ nor catecholamine levels were modified by rhIGF-I administration, while insulin and glucose levels showed a slight but significant decrease. Basal left ventricular ejection fraction $(61.8 \pm 2.0 \%)$ significantly increased at $+180 \mathrm{~min}$ after rhIGF-I $(65.3 \pm 2.7 \%, P<0.03)$. No change was recorded in mean blood pressure while a non-significant trend towards a reduction of heart rate was present by +120 min. Conclusions: These findings indicate that even subcutaneous administration of a low dose of rhIGF-I has acute inotropic effects as evaluated by radionuclide angiocardiography in healthy adults.
\end{abstract}

European Journal of Endocrinology $140322-327$

\section{Introduction}

Recent evidence indicates that the activity of the growth hormone (GH)/insulin-like growth factor (IGF-I) axis has important influences on myocardial function, which may explain cardiac abnormalities evidenced in GH hyper- and hyposecretory states in both humans and other animals (1).

IGF-I, as well as GH, possesses specific receptors at the myocardial level (1-3). IGF-I synthesis in and release from myocardial tissue have been demonstrated and they are probably involved in the auto/paracrine actions of the peptide (4-11). In addition to growthpromoting and metabolic actions, IGF-I has specific cardiovascular effects. It specifically stimulates heart, but not skeletal muscle growth, induces mRNA expression for specific contractile proteins, myocyte hypertrophy and contractility and has cardioprotective effects (11-21). In fact, reduced cardiac mass and performance are present in GH deficiency but are counteracted by a recombinant human (rh) GH replacement therapy restoring IGF-I levels $(1,22-26)$. More recently, in keeping with animal data $(15,16,27$, 28 ), acute intravenous infusion or subcutaneous rhIGF-I administration to healthy subjects has also been reported to be capable of improving cardiac performance evaluated by impedance cardiography or echocardiography respectively $(29,30)$. The intravenous infusion of $60 \mu \mathrm{g} / \mathrm{kg}$ IGF-I over $3 \mathrm{~h}$ induced overt systemic side-effects in addition to metabolic changes (29) while the same rhIGF-I dose injected subcutaneously did not induce side-effects or modify glucose but inhibited insulin levels as well as the GH response to physical exercise (30).

Based on the foregoing, the aim of our study was to evaluate the effects of a low rhIGF-I dose $(20 \mu \mathrm{g} / \mathrm{kg}$ s.c. $)$ 
on cardiac performance in healthy adults using radionuclide angiocardiography. Radionuclide imaging was chosen because of its high reliability in evaluating cardiac performances $(31,32)$.

The effects of rhIGF-I on circulating IGF-I, GH, insulin, glucose and catecholamine levels were also studied.

\section{Materials and methods}

\section{Study design and protocol}

Six healthy male volunteers (mean \pm s.E.M.: age, $35.7 \pm 4.3$ years; body mass index, $22.4 \pm 0.5 \mathrm{~kg} / \mathrm{m}^{2}$ ) gave their informed consent to the study which had been approved by the local, independent ethical committee. No subject had any history of hypertension, cardiovascular, renal, respiratory, hepatic or metabolic diseases and none was taking medication. Physical examination, blood pressure, electrocardiographic and echocardiographic findings were also normal.

On the day of the study, subjects had breakfast at $0800 \mathrm{~h}$ and were admitted to the study room $2 \mathrm{~h}$ before the beginning of the testing session $(1600 \mathrm{~h})$. The study room was maintained in constant conditions of temperature and light, and in the absence of noise.

An antecubital vein was cannulated for blood sampling and kept patent by slow infusion of isotonic saline. ECG was continuously monitored in lead II. Blood pressure was monitored with an automated apparatus (SpaceLabs Inc., Redmond, WA, USA). Forty-five minutes after relaxing in the recumbent position, all subjects underwent subcutanenous administration of rhIGF-I (Pharmacia \& Upjohn, Stockholm, Sweden; $20.0 \mu \mathrm{g} / \mathrm{kg}$ at $0 \mathrm{~min}$ ). Haemodynamic and hormonal parameters were evaluated basally and then every $30 \mathrm{~min}$ from +90 up to $+180 \mathrm{~min}$.

\section{Hormonal parameters: analytical methods}

Serum IGF-I levels $(\mu \mathrm{g} / \mathrm{l})$ were measured in duplicate by RIA (Nicholls Institute Diagnostics, San Juan Capistrano, CA, USA) after acid-ethanol extraction to avoid the interference of binding proteins. The sensitivity of the assay was $0.2 \mu \mathrm{g} / \mathrm{l}$. The inter- and intra-assay coefficients of variation were $8.8-10.8 \%$ and $5.0-9.5 \%$ respectively. In our laboratory, the $3 \mathrm{rd}$ and 97 th centile limits of normal IGF-I in adulthood are 65 and $385 \mu \mathrm{g} / \mathrm{l}$ respectively.

Serum GH levels $(\mu \mathrm{g} / \mathrm{l})$ were measured in duplicate by IRMA (hGH-CTK; Diasorin Biomedica, Saluggia, Italy). The sensitivity of the assay was $0.15 \mu \mathrm{g} / \mathrm{l}$. The inter- and the intra-assay coefficients of variation were $2.9-4.5 \%$ and $2.4-4.0 \%$ respectively.

Serum insulin levels $(\mu \mathrm{U} / \mathrm{ml})$ were measured in duplicate by RIA (INSIK-5; Diasorin Biomedica). The sensitivity of the assay was $4.0 \mu \mathrm{U} / \mathrm{ml}$. The inter- and intra-assay coefficients of variation were $5.9-6.3 \%$ and $3.5-8.7 \%$ respectively.
Plasma glucose levels $(\mathrm{mg} / \mathrm{dl})$ were measured by a gluco-oxidase colorimetric method (Menarini Diagnostics, Florence, Italy).

Plasma epinephrine (E) and norepinephrine (NE) levels (ng/l) were assayed after extraction with alumina using high-performance liquid chromatography with electrochemical detection. The sensitivity of the assay was $5.0 \mathrm{ng} / \mathrm{l}$. The inter- and the intra-assay coefficients of vari-ation were $8.5 \%$ and $4 \%$ respectively for $\mathrm{E}$, and $7 \%$ and $3 \%$ respectively for NE.

\section{Radionuclide imaging methods}

Equilibrium radionuclide angiocardiography was performed after in vitro labelling of red blood cells with $925 \mathrm{Mbq}(25 \mathrm{mCi})$ of ${ }^{99 \mathrm{~m}} \mathrm{Tc}$.

Subjects were imaged supine in the best septal anterior oblique projection. Acquisition and processing were made using a $400 \mathrm{~T}$ GE scintillation camera, equipped with a low energy, all purpose parallel hole collimator, using 24 frames/cycle, $64 \times 64$ matrices and a $\times 1.6$ zoom factor. Data processing was performed using a standard, highly reproducible, validated semiautomatic procedure, involving multiple regions of interest and background subtraction.

Left ventricular ejection fraction (LVEF) was calculated from the left ventricular curve. Right ventricle ejection fraction was estimated using a method of two regions of interest. Absolute left ventricular end-systolic volume and end-diastolic volume (LVEDV) were calculated using a validated non-geometric method (33).

Mean (MBP), systolic, and diastolic blood pressure as well as heart rate (HR) were measured at each timepoint. Stroke volume (SV), cardiac output (CO) and systemic vascular resistance (SVR) were derived from the other measured parameters.

Eight-minute repeated acquisitions were made basally and for the first $8 \mathrm{~min}$ of each 30-min period from +90 to $+180 \mathrm{~min}$. For each acquisition, a minimum of 8000000 counts was acquired.

\section{Statistical analysis}

Results are expressed as mean \pm s.E.M. Haemodynamic parameters are expressed as absolute values or as percent changes from baseline. Hormonal parameters are expressed either as absolute values or as areas under curves, calculated by trapezoidal integration. Data were analyzed using ANOVA for repeated measurement (Friedman two-way), followed by Wilcoxon signed rank test where appropriate.

\section{Results}

\section{Hormonal parameters}

Administration of rhIGF-I increased circulating IGF-I (peak at +150 min vs baseline: $330.2 \pm 9.6$ vs 
$199.7 \pm 8.7 \mu \mathrm{g} / \mathrm{l}, \quad P<0.03)$ to levels which remained similar up to $+180 \mathrm{~min}$ (Fig. 1). Following s.c. rhIGF-I administration $\mathrm{GH}$ levels showed no significant changes $(+150 \mathrm{~min}: \quad 0.1 \pm 0.1$ vs baseline, $0.3 \pm$ $0.1 \mu \mathrm{g} / \mathrm{l})$ (Fig. 1).

Catecholamine levels were not modified by IGF-I administration (E, peak at +180 min: $55.3 \pm 14.2$ vs
$47.8 \pm 9.7 \mathrm{ng} / \mathrm{l} ; \mathrm{NE}$, peak at $+180 \mathrm{~min}: 248.2 \pm 20.8$ vs $236.8 \pm 16.4 \mathrm{ng} / \mathrm{l}$ (Fig. 1 and Table 1 ). On the other hand, a slight but significant decrease in both glucose (nadir at $+150 \mathrm{~min}$ : $67.3 \pm 3.7$ vs baseline: $84.3 \pm 1.7 \mathrm{mg} / \mathrm{dl}, P<0.03$ ) and insulin levels (nadir at $+180 \mathrm{~min}: 5.3 \pm 0.2$ vs baseline: $12.1 \pm 1.3 \mu \mathrm{U} / \mathrm{ml}$, $P<0.03)$ was observed after rhIGF-I administration.
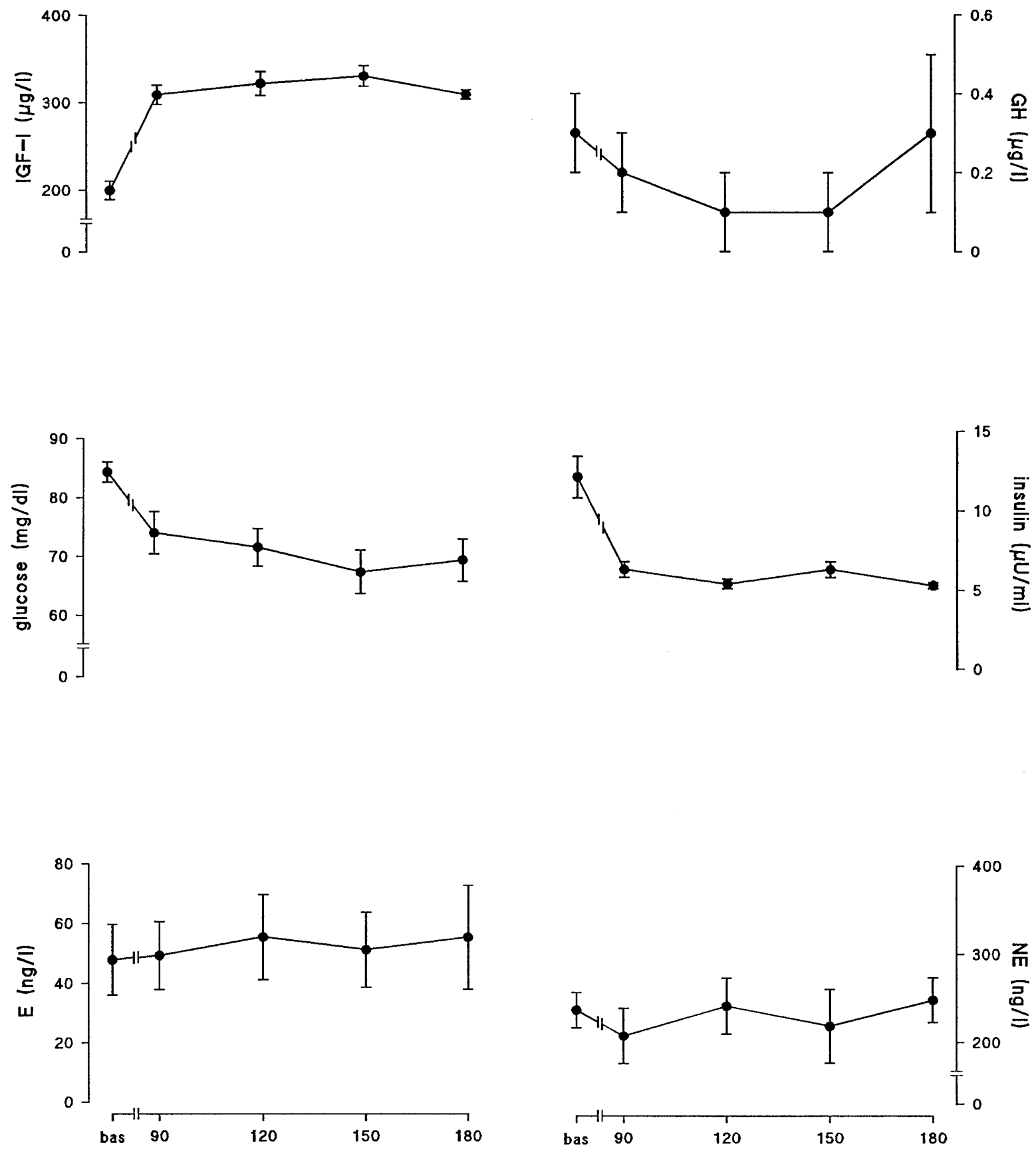

time (min)

Figure 1 Mean \pm S.E.M. circulating levels of IGF-I, GH, glucose, insulin, epinephrine (E), and norepinephrine (NE) at baseline (bas) and after rhlGF-I administration in six normal male volunteers. 
Table 1 Effects of rhIGF-I administration on haemodynamic and hormonal parameters in six normal male volunteers

\begin{tabular}{|c|c|c|c|c|c|}
\hline & Baseline & $90 \mathrm{~min}$ & $120 \mathrm{~min}$ & $150 \mathrm{~min}$ & $180 \mathrm{~min}$ \\
\hline LVEF (\%) & $61.8 \pm 2.9$ & $63.5 \pm 3.1$ & $62.0 \pm 3.1$ & $64.3 \pm 2.6$ & $65.3 \pm 2.7^{*}$ \\
\hline LVEDV (ml) & $120.0 \pm 6.8$ & $115.8 \pm 8.0$ & $119.7 \pm 8.2$ & $121.7 \pm 7.3$ & $122.5 \pm 6.8$ \\
\hline $\mathrm{SV}(\mathrm{ml})$ & $74.2 \pm 5.5$ & $73.5 \pm 6.3$ & $74.4 \pm 6.6$ & $77.8 \pm 4.2$ & $79.6 \pm 4.3$ \\
\hline $\mathrm{CO}(\mathrm{I} / \mathrm{min})$ & $5.0 \pm 0.4$ & $5.0 \pm 0.6$ & $4.6 \pm 0.5$ & $4.9 \pm 0.4$ & $5.0 \pm 0.4$ \\
\hline $\mathrm{MBP}(\mathrm{mmHg})$ & $90.2 \pm 4.6$ & $87.8 \pm 3.9$ & $91.1 \pm 6.9$ & $86.3 \pm 4.3$ & $87.6 \pm 5.4$ \\
\hline HR (beats/min) & $67.0 \pm 2.3$ & $68.0 \pm 5.4$ & $61.7 \pm 4.0$ & $63.0 \pm 4.1$ & $63.0 \pm 4.0$ \\
\hline SVR (dyn.s.cm $\left.{ }^{-5}\right)$ & $1506.6 \pm 145.9$ & $1472.2 \pm 138.8$ & $1634.5 \pm 120.5$ & $1447.1 \pm 108.0$ & $1429.9 \pm 113.5$ \\
\hline$E(\mathrm{ng} / \mathrm{l})$ & $47.8 \pm 9.7$ & $49.2 \pm 9.3$ & $55.3 \pm 11.7$ & $51.2 \pm 10.3$ & $55.3 \pm 14.2$ \\
\hline NE (ng/l) & $236.8 \pm 16.4$ & $207.3 \pm 25.5$ & $241.3 \pm 25.9$ & $218.7 \pm 34.3$ & $248.2 \pm 20.8$ \\
\hline
\end{tabular}

${ }^{*} P<0.03$ vs baseline.

E, epinephrine; NE, norepinephrine.

\section{Haemodynamic parameter}

Basal LVEF was $61.8 \pm 2.0 \%$. Following rhIGF-I administration LVEF did not vary up to +120 min but then showed an increase which was significant at $+180 \mathrm{~min}$ after rhIGF-I $(65.3 \pm 2.7 \%, \quad P<0.03$ vs baseline $)$. Individual LVEF responses to rhIGF-I are reported in Fig. 2. No change was observed in any of the other measured haemodynamic parameters, including LVEDV. A trend towards an increase in SV and a decrease in HR was apparent, resulting in no change of CO (Fig. 2 and Table 1). No change was recorded in systolic and diastolic blood pressure.

\section{Side-effects}

Transient pain in the injection site was recorded in all subjects after rhIGF-I administration. No clear general side-effects were recorded but, late after rhIGF-I administration, all subjects complained of fatigue and of not being well.

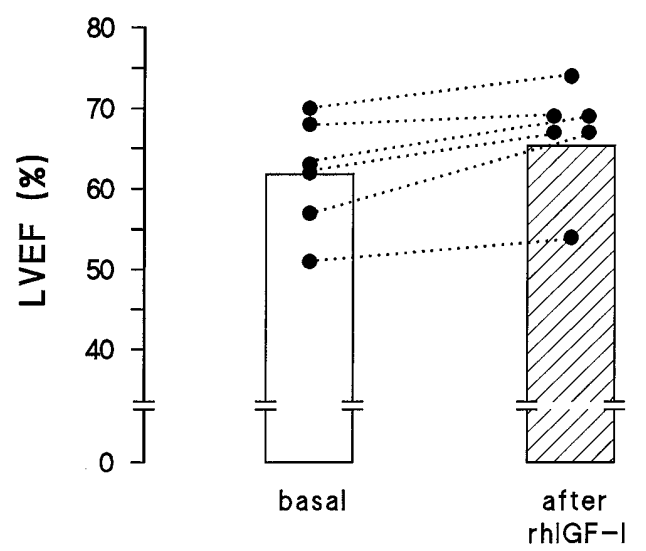

Figure 2 Mean and individual LVEF variations at baseline and after rhlGF-I administration in six normal male volunteers.

\section{Discussion}

The results of the present study show that the acute rhIGF-I administration enhances cardiac inotropism in normal humans even after s.c. injection of a low dose.

The increase in circulating IGF-I levels that we found in the present study after the subcutaneous administration of $20 \mu \mathrm{g} / \mathrm{kg}$ rhIGF-I overlaps with that reported by other authors $(1,34-37)$ and it must be emphasized that it remained within the high normal range of basal IGF-I levels in adulthood (38). Thus, this suggests that we were investigating the effects of 'physiological' IGF-I doses.

In our study, rhIGF-I administration did not significantly inhibit spontaneous GH levels in spite of the well-known inhibitory action of IGF-I on somatotroph secretion $(36,39,40)$. The lack of a significant inhibitory effect of rhIGF-I on somatotroph secretion in our study could be due to the fact that we did not perform frequent sampling and ultrasensitive GH assays (39).

In agreement with previous studies (29, 30, 34), insulin and glucose levels showed a reduction after rhIGF-I administration. On the other hand, after $20 \mu \mathrm{g} /$ $\mathrm{kg}$ (present study) as well as after $60 \mu \mathrm{g} / \mathrm{kg}$ rhIGF-I s.c. (30) catecholamine levels did not show any significant variation while they have been shown to be increased by higher rhIGF-I doses leading to hypoglycaemia (34).

An inotropic effect of acute rhIGF-I administration had already been reported both in animals $(15,16$, $27,28)$ and in humans $(29,30)$. In fact, acute intravenous or subcutaneous rhIGF-I administration has been found to be capable of improving cardiac performance evaluated by impedance cardiography or echocardiography, respectively, in healthy adults $(29,30)$. The intravenous infusion of $60 \mu \mathrm{g} / \mathrm{kg}$ over $3 \mathrm{~h}$ induced systemic side-effects and, in addition, metabolic changes (29), while the same dose injected subcutaneously did not induce side-effects but still inhibited insulin levels and blunted the $\mathrm{GH}$ response to physical exercise (30). 
Our present findings, although from a nonrandomized study, show that acute rhIGF-I administration enhances cardiac inotropism in humans even after subcutaneous injection of a dose so low as to maintain circulating IGF-I levels within the normal range.

The validity of these findings is strengthened by the use of radionuclide angiocardiography, a technique which is much more reliable than echocardiography $(31,32)$, for measuring cardiac performances.

The increase in LVEF after rhIGF-I could be due to a direct cardiac effect or, alternatively, to a reflection of vasodilatation. Indeed, vasodilatory effects of rhIGF-I in human forearm muscles and kidney have been reported (41-45). However, in humans in vivo after $20 \mu \mathrm{g} / \mathrm{kg}$ (present study) as well as after $60 \mu \mathrm{g} / \mathrm{kg}$ rhIGF-I $(29,30)$, no significant change in SVR was found. Another explanation for increased LVEF could rely on an enhanced catecholamine secretion; again, no changes were found in epinephrine and norepinephrine levels by us or by others (30).

The hypothesis that IGF-I has a direct positive inotropic effect is supported by the evidence that it has an inotropic effect in neonatal rat cardiomyocites (27) and in the isolated rat heart (28). It is therefore reasonable to speculate that the increase in ventricular isometric force development caused by IGF-I in man could be linked either to a sensitization of cardiac neurofilaments to $\mathrm{Ca}^{2+}$ without modifying high energy phosphate metabolism (46) or the enhancement of peak cytosolic $\mathrm{Ca}^{2+}$ concentration on cardiac myocites (47).

In contrast to another study which was performed during physical exercise (30), we found that the increase in the LVEF was coupled with a non-significant increase in SV; no change was recorded in CO, likely due to the concomitant reduction of HR. In previous studies, an increase in HR occurred after intravenous IGF-I infusion but not after subcutaneous injection $(29,30)$.

Interestingly, in early stage acromegaly an increased cardiac contractility has been shown while GH-deficient adults have impaired cardiac performances (1-3). These findings could be explained in part by the stimulatory effects of $\mathrm{GH}$ on circulating and locally produced IGF-I $(1-3,14,45,48,49)$ since no direct effect of GH has been found on cultured cardiomyocites (12-14). Moreover, although acute inotropic effects of rhGH administration have been reported (50) in a study protocol which overlapped with the present one, we found no effect of acute intravenous rhGH on cardiac contractility in normal adults (51).

In conclusion, the present study shows that acute subcutaneous administration of a low rhIGF-I dose leading to an increase of circulating IGF-I levels within the high normal range induced a delayed increase in cardiac inotropism in healthy human subjects.

\section{Acknowledgements}

This study was supported by MURST (Ministero Università e Ricerca Scientifica), FSMEM (Fondazione Studio Malattie Endocrino-Metaboliche), Pharmacia \& Upjohn. The authors wish to thank Professor Franco Camanni and Dr Emanuela Arvat for their co-operation in the study and revision of the manuscript.

\section{References}

1 Saccà L, Cittadini A \& Fazio S. Growth hormone and the heart. Endocrine Reviews 199415 555-573.

2 Isgaard J \& Friberg P. Regulation of insulin-like growth factor I (IGF-I) and receptors for IGF-I and growth hormone in the heart. Endocrinology and Metabolism 19974 (Suppl B) 15-19.

3 Mathews LS, Enberg B \& Norstedt G. Regulation of rat growth hormone receptor gene expression. Journal of Biological Chemistry $1989179905-9910$.

4 Murphy LJ, Bell GI, Duckworth L \& Friesen G. Identification, characterization and regulation of a rat complimentary deoxyribonucleic acid which encodes insulin-like growth factor I. Endocrinology $1987121684-691$.

5 Guron G, Friberg P, Wickman A, Brantsing C, Gabrielsson B \& Isgaard J. Cardiac insulin-like growth factor I and growth hormone receptor expression in renal hypertension. Hypertension $199627636-642$.

6 Isgaard J, Wahlander H, Adams MA \& Friberg P. Increased expression of growth hormone receptor mRNA and insulin-like growth factor I mRNA in volume overloaded hearts. Hypertension $199423884-888$.

7 Russel-Jones DL, Leach RM, Ward JPT \& Thomas CR. Insulin-like growth factor-I gene expression is increased in the right ventricle hypertrophy induced by chronic hypoxia in the rat. Journal of Molecular Endocrinology 199310 99-102.

8 Delafontaine P. Insulin-like growth factor I and its binding proteins in the cardiovascular system. Cardiovascular Research $199530825-834$.

9 Engelmann GL, Boehm KD, Haskell JF, Khairallah PA \& Ilan J. Insulin-like growth factors and neonatal cardiomyocyte development: ventricular gene expression and membrane receptor variations in normotensive and hypertensive rats. Molecular and Cellular Endocrinology 198963 1-14.

10 Guse AH, Kiess W, Funk B, Kessler U, Berg I \& Gercken G. Identification and characterization of insulin-like growth factor receptors on adult rat cardiac myocytes: linkage to inositol 1,4,5-trisphosphate formation. Endocrinology $1992130145-$ 151 .

11 Isgaard J, Nilsson A, Vilkman K \& Isaksson OGP. Growth hormone regulates the level of insulin-like growth factor mRNA in rat skeletal muscle. Journal of Endocrinology 1989120 107-112.

12 Donath MY, Zapf J. Eppenberger-Eberhardt M, Froesch ER \& Eppenberger HM. Insulin-like growth factor I stimulates myofibril development and decreases smooth muscle-actin of adult cardiomyocytes. Proceedings of the National Academy of Sciences of the USA 199491 1686-1690.

13 Donohue TJ, Dworkin LD, Lango MN, Fliegner K, Lango RP, Benstein JA et al. Induction of myocardial insulin-like growth factor-I gene expression in left ventricular hypertrophy. Circulation $199489799-809$.

14 Ito H, Hiroe M, Hirata Y, Tsujino M, Adachi S, Shichiri M et al. Insulin-like growth factor-I induces hypertrophy with enhanced expression of muscle specific genes in cultured rat cardiomyocytes. Circulation 199387 1715-1721.

15 Duerr RL, Huang S, Miraliakbar HR, Clark R, Chien KR \& Ross J. Insulin-like growth factor-I enhances ventricular hypertrophy and function during the onset of experimental cardiac failure. Journal of Clinical Investigation 199595 619-627. 
16 Cittadini A, Stromer H, Katz SE, Clark R, Moses AC, Morgan JP et al. Differential cardiac effects of growth hormone and insulinlike growth factor $\mathrm{I}$ in the rat. A combined in vivo and in vitro evaluation. Circulation 199693 800-809.

17 Florini JR \& Ewton DZ. Induction of gene expression in muscle by IGFs. Growth Regulation 19922 23-29.

18 Guler HP, Schmid C, Zapf J \& Froesch ER. Effects of recombinant insulin-like growth factor I on insulin secretion and renal function in normal human subjects Proceedings of the National Academy of Sciences of the USA 198886 326-330.

19 Fuller J, Mynett JR \& Sugden PH. Stimulation of cardiac protein synthesis by insulin-like growth factors. Biochemical Journal 1992 282 85-90.

20 Buerke M, Murohara T, Skurk C, Nuss C, Tomaselli K \& Lefer AM. Cardioprotective effect of insulin-like growth factor I in myocardial ischemia followed by reperfusion. Proceedings of the National Academy of Sciences of the USA 199592 8031-8035.

21 Ambler GR, Johnston BM, Maxwell L, Gavin JB \& Gluckmann PD. Improvement of doxorubicin induced cardiomyopathy in rats treated with insulin-like growth factor I. Cardiovascular Research $1993271368-1373$.

22 Johannsson G, Bengtsson BA, Andersson B, Isgaard J \& Caidahl K. Long-term cardiovascular effects of growth hormone treatment in GH-deficient adults. Preliminary data in a small group of patients. Clinical Endocrinology 199645 305-314.

23 Amato G, Carella C, Fazio S, La Montagna G, Cittadini A, Sabatini D et al. Body composition, bone metabolism and heart structure and function in growth hormone $(\mathrm{GH})$-deficient adults before and after $\mathrm{GH}$ replacement therapy at low doses. Journal of Clinical Endocrinology and Metabolism 199377 1671-1676.

24 Merola B, Cittadini A, Colao A, Longobardi S, Fazio S, Sabatini D et al. Cardiac structural and functional abnormalities in adult patients with growth hormone deficiency. Journal of Clinical Endocrinology and Metabolism 199377 1658-1661.

25 Fazio S, Biondi B, Sabatini D, Cuocolo A, Tommaselli AP, Lombardi $\mathrm{G}$ et al. Long-term growth hormone deficiency as a cause of cardiomyopathy and its reversibility with specific replacement therapy. Journal of Clinical Endocrinology and Metabolism $199681887-890$.

26 Valcavi R, Gaddi O, Zini M, Iavicoli M, Mellino V \& Portioli I. Cardiac performance and mass in adults with hypopituitarism: effect of one year of growth hormone treatment. Journal of Clinical Endocrinology and Metabolism 199580 659-666.

27 Vetter U, Kupferschmid C, Lang D \& Pentz S. Insulin-like growth factors and insulin increase the contractility of neonatal rat cardiocytes in vitro. Basic Research in Cardiology 199883 647-654.

28 Johnston DM, Gluckmann PD, Bratt CM, Ambler GR \& Lubbe WF. Insulin-like growth factors elicit positive inotropic responses in isolated rat heart. Growth Regulation 1994444 (Abstract).

29 Russel Jones DL, Bates AI, Umpleby AM, Hennessy TR, Bowes SB, Hopkins KD et al. A comparison of the effect of IGF-I and insulin on glucose metabolism, fat metabolism and the cardiovascular system in normal human volunteers. European Journal of Endocrinology 199525 403-411.

30 Donath MY, Jenni R, Brunner HP, Anrig M, Kohli S, Glatz Y et al. Cardiovascular and metabolic effects of insulin-like growth factor$\mathrm{I}$ at rest and during exercise in humans. Journal of Clinical Endocrinology and Metabolism 199681 4089-4094.

31 Burow RD, Strauss HW, Singleton R, Pond M, Rehn T, Bailey IK et al. Analysis of left ventricular function from multiple gated acquisition cardiac blood pool imaging. Comparison to contrast angiography. Circulation 197756 1024-1028.

32 Okada RD, Kirshenbaum HD, Kushner FG, Strauss HW, Dinsmore RE, Newell JB et al. Observer variance in the qualitative evaluation of left ventricular wall motion and the quantitation of left ventricular ejection fraction using rest and exercise multigated blood pool imaging. Circulation 199061 128-136.

33 Links JM, Becker LC, Shindledecker JG, Guzman P, Burow RD, Nickoloff EL et al. Measurement of absolute left ventricular volume from gated blood pool studies. Circulation $19826582-91$.
34 Kerr D, Tamborlane WV, Rife F \& Sherwin RS. Effects of IGF-I on the responses to and recognition of hypoglycaemia in humans. Journal of Clinical Investigation 199391 141-143.

35 Ghigo E, Gianotti L, Arvat E, Ramunni J, Valetto MR, Broglio F et al. Effect of rhIGF-I administration on GH secretion both spontaneous and stimulated by GHRH or Hexarelin, a peptidyl GH secretagogue, in humans. Journal of Clinical Endocrinology and Metabolism 199984 285-290.

36 Vaccarello MA, Diamon FB, Guevara-Aguirre J, Rosenbloom AL, Fielder PJ, Gargosky S et al. Hormonal and metabolic effects and pharmacokinetics of recombinant insulin-like growth factor-I in growth hormone receptor deficiency - Laron syndrome. Journal of Clinical Endocrinology and Metabolism 199377 273-280.

37 Trainer PJ, Holly J, Medbak S, Rees LH \& Besser GM. The effect of recombinant IGF-I on anterior pituitary function in healthy volunteers. Clinical Endocrinology 199441 515-522.

38 Ghigo E, Aimaretti G, Gianotti L, Bellone J, Arvat E \& Camanni F. New approach to the diagnosis of growth hormone deficiency in adults. European Journal of Endocrinology 1996134 352-356.

39 Hartman ML, Clayton PE, Johnson ML, Celnikel A, Periman AJ, Alberti KGMM \& Thorner MO. A low dose euglycemic infusion of recombinant human insulin-like growth factor I rapidly suppresses fasting-enhanced pulsatile growth hormone secretion in humans. Journal of Clinical Investigation 199391 2453-2462.

40 Jones J \& Clemmons DR. Insulin-like growth factors and their binding proteins: biological actions. Endocrine Reviews 199516 3-34.

41 Guler HP, Schmid C, Zapf J \& Froesch ER. Effect of recombinant insulin-like growth factor I on insulin secretion and renal function in normal human subjects. Proceedings of the National Academy of Sciences of the USA 198986 2868-2872.

42 Copland AC \& Nair KS. Recombinant human insulin-like growth factor I increases forearm blood flow. Journal of Clinical Endocrinology and Metabolism 199479 230-232.

43 Fryburg DA. IGF-I exerts GH and insulin-like actions on human muscle protein metabolism. American Journal of Physiology 1994 267 E331-E336.

44 Kiowski LV, Stoschisky K, Kim JH, Hussain MA \& Froesch ER. Insulin-like growth factor I causes endothelium-dependent arterial vasodilatation. Circulation 199490 I-242 (Abstract).

45 Hirschberg R \& Kopple JD. Evidence that insulin-like growth factor I increases renal plasma flow and glomerular filtration rate in fasted rats. Journal of Clinical Investigation 198983 326-330.

46 Stromer H, Cittadini A, Douglas PA \& Morgan JP. Exogenously administered growth hormone and insulin-like growth factor I alter intracellular $\mathrm{Ca}^{2+}$ handling and enhance cardiac performance. Circulation Research 199679 227-236.

47 Firestone NS, Ribaric S \& Mason WT. The effect of insulin-like growth factor-I on adult rat cardiac contractility. Molecular and Cellular Biochemistry 1996164 223-229.

48 Isgaard J, Nillson A, Vikman K \& Isaksson OGP. Growth hormone regulates the level of insulin-like growth factor I mRNA in rat skeletal muscle. Journal of Endocrinology $1989120107-112$.

49 Gosteli-Peter MA, Winterhalter KH, Schmid C, Froesch ER \& Zapf J. Expression and regulation of insulin-like growth factor I (IGF-I) and IGF binding protein messenger ribonucleic acid levels in tissues of hypophysectomized rats infused with IGF-I and growth hormone. Endocrinology 1994135 2558-2567.

50 Volterrani M, Desenzani P, Lorusso R, d'Aloia A, Manelli F \& Giustina A. Haemodynamic effects of intravenous growth hormone in congestive heart failure. Lancet 1997359 1067-1068.

51 Bisi G, Podio V, Valetto MR, Broglio F, Bertuccio G, Boghen MF et al. The acute administration of Hexarelin, a synthetic GHreleasing hexapeptide, but not growth hormone, increases left ventricular ejection fraction in humans. Circulation 199796 I361 (Abstract).

Received 26 October 1998

Accepted 14 January 1999 